\title{
PENGARUH KOMPENSASI DAN DISIPLIN KERJA TERHADAP KINERJA KARYAWA PADA PT. MULIA SUKSES JAYA DI BOGOR
}

\author{
Muhammad Ridwan, Ahmad Muharomi \\ Program Studi Manajemen Universitas Islam As-Syafi'iyah \\ Email :m_ried88@yahoo.com
}

\begin{abstract}
Every company wants the goals set can be achieved in a timely manner. Therefore, it is necessary to have a good management of human resources owned by a company. In this study to determine the effect of variables with the title "Effect of Work Compensation and Discipline on Employee Performance. This research was conducted on the employees of PT. Mulia Sukses Jaya with 30 respondents and using saturated sampling technique so the sample used is all populations, namely 30. Analysis techniques using correlation and regression analysis and hypothesis testing $t$ and $f$ as well as the coefficient of determination $R 2$ with data processing using SPSS26.

Based on the results of data analysis from the test the value of tcount 2,192>2,052 ttable. And the sig value of $0.037<0.05$ means that Ha is accepted and Ho is rejected then Compensation has a significant effect on Employee Performance. While work discipline has a value of 5.074> 2.052 ttable and a sig value of $0.000<0.05$ which means that Work Discipline has a significant effect on Employee Performance. Based on the $f$ test results the fvalue of 12.704> 3.35 ftabel value and the value of the significance level of $0.000<0.05$. With this, Ha is accepted and Ho is rejected, which means Compensation and Work Discipline together - positive and significant effect on Employee Performance at PT. Mulia Sukses Jaya. The coefficient of determination is 0.485 which means that compensation and work discipline have an effect of $48.5 \%$ on employee performance. The remaining $51.5 \%$ is influenced by other factors outside the variables of this study.
\end{abstract}

Keywords: Compensation, Work Discipline and employee performance

\begin{abstract}
Abstrak
Setiap perusahaan menginginkan agar tujuan yang ditetapkan dapat tercapai dengan tepat waktu. Oleh karena itu, diperlukan pengelolaan yang baik sumber daya manusia yang dimilki suatu perusahaan. Dalam penelitian ini untuk mengetahui pengaruh variable dengan judul "Pengaruh Kompensasi dan Disiplin Kerja Terhadap Kinerja Karyawan. Penelitian ini dilakukan pada karyawan PT. Mulia Sukses Jaya dengan populasi sebanyak 30 dan menggunakan teknik sampling jenuh jadi sample yang digunakan adalah semua populasi yaitu 30. Teknik analisis menggunakan analisis korelasi dan regresi dan uji hipotesa $\mathrm{t}$ dan $\mathrm{f}$ serta koefisen determinasi $\mathrm{R}^{2}$ dengan pengolahan data menggunakan SPSS 26.

Berdasarkan hasil dari analisis data dari ujit nilai $t_{\text {hitung }} 2,192>2,052 t_{\text {table. }}$. Dan nilai sig 0,037 <0,05 artinya bahwa Ha ditermia dan Ho ditolak maka Kompensasi
\end{abstract}


berpengaruh signifikan terhadap Kinerja Karyawan. Sedangkan disiplin kerja mempunyai nilai thitung $5.074>2,052$ ttable dan nilai sig sebesar $0,000<0,05$ yang berarti bahwa Disiplin Kerja berpengaruh signifikan terhadap Kinerja Karyawan. Berdasarkan hasil uji f nilai fhitung 12,704 > 3,35 nilai ftabel dan nilai taraf signifikasi $0.000<0,05$. Dengan ini maka Ha diterima dan Ho ditolak yang artinya Kompensasi dan Disiplin Kerja secara bersama - sama berpengaruh positif dan signifikan terhadap Kinerja Karyawan pada PT.mulia Sukses Jaya. Koefisen determinasi sebesar 0,485 yang artinya kompensasi dan disiplin kerja mempunyai pengaruh $48.5 \%$ terhadap Kinerja karyawan. Sisanya 51,5\% dipengaruhi faktor lainya diluar variable penelitian ini.

Kata Kunci :Kompensasi, Disiplin Kerja dan Kompensasi.

\section{Pendahuluan}

\subsection{Latar Belakang Masalah}

Setiap perusahaan menginginkan agar tujuan yang ditetapkan dapat tercapai dengan tepat waktu. Oleh karena itu, diperlukan pengelolaan yang baik sumber daya manusia yang dimilki suatu perusahaan. Pentingnya sumber daya manusia karena faktor manusia sebagai pelaku utama dalam kegiatan oprasional perusahaan. Melalui perencanaan sumber daya manusia yang matang dan faktor-faktor yang mendukung keberhasilan mengelola sumber daya manusia dalam perusahaan seperti pemberian kompensasi, disiplin kerja, rekruitmen, pelatihan, motivasi kerja, lingkungan kerja, kepuasan kerja, budaya organisasi dan lainya yang dapat mempengaruhi Kinerja Karyawan dalam perusahaan. Bintoro dkk (2017:106) mengemukakan: "Kinerja adalah hasil kerja baik kualitas maupun kuantitas yang dicapai oleh seseorang dalam melaksankan tugas sesuai tanggung jawab yang diberikan”. Tujuan perusahaan untuk mendapatkankan hasil yang maksimal tidak akan terwujud bila kinerja karyawannya lemah. Lemahnya kinerja karyawan dalam suatu perusahaan bisa disebabkan oleh banyak faktor yang terkait. Perusahaan harus tanggap dalam menangani masalah kinerja karyawan yang ada dalam organisasi perusahaan. Tidak tanggap nya perusahaan dalam menyikapi lemahnya kinerja karyawan akan memberikan dampak pada kelancaran kerja dalam perusahaan.

PT.Mulia Sukses Jaya adalah perusahaan yang bergerak di bidang distributor elektronik rumah tangga, yang berdiri tahun 1999 dan berlokasi Warehouse di daerah Klapanunggal - Cileungsi Kabupaten Bogor. Perusahaan ini menjual alat elektronik dapur seperti kompor, penyedot asap, dispenser, oven dan lain sebagainya. PT. Mulia Sukses Jaya sebagai perusahaan distributor, harus bisa mendistribusikan barang ke konsumen secara cepat dan tepat waktu. Pendistribusian secara cepat dan tepat waktu kepada konsumen membuat kepercayaan konsumen terhadap produk bisa meningkat. Tetapi dalam masalah ini terjadi kelemahan Kinerja pada karyawan bagian delivery dalam hal pendistribusian barang. Permasalahan yang sering terjadi adalah dalam hal keterlambatan dan tidak selesainya pengiriman kepada konsumen menjadi permasalahan yang harus diperhatikan oleh perusahaan. Penurunan Kinerja dalam pendistribusian barang ini bisa dilihat dari data pengriman barang yang diambil dari bulan Januari 2019 - Juli 2019. Penurunan Kinerja Karyawan pada PT.Mulia Sukses Jaya bisa disebabkan oleh banyak faktor yang terkait, diantaranya adalah Kompensasi 
dan Disiplin Kerja. Pemberian Kompensasi yang belum sesuai apa yang diharapkan oleh karyawan dapat mengakibatkan penurunan Kinerja pada karyawan. Kompensasi mencerminkan upaya perusahaan untuk mempertahankan sumber daya manusia yang dimiliki. Pemberian Kompensasi yang semakin baik akan mendorong karyawan untuk bekerja semakin baik dan produktif, maka akan tercapai tujuan perusahaan. Hamali (2016:80) mengemukakan bahwa "semua jenis penghargaan yang berupa uang atau bukan uang yang diberikan kepda karyawan secara layak dan adil atas jasa yang diberikan dalam mencapai tujuan perusahaan."

Permasalahan lain dalam perusahaan yang dapat menurunkan kinerja karyawan adalah disiplin kerja. Disiplin Kerja merupakan faktor penting dalam usaha untuk meningkatkan Kinerja Karyawan. Hasibuan (2013:83) menyatakan bahwa "merupakan kesadaran dan kesedian seseorang dalam menaati semua peraturanperaturan perusahaan dan norma-norma yang berlaku”. Kurangnya Disiplin kerja pada karyawan bagian delivery dapat mempengaruhi penurunan kinerja dalam hal pendistribusian barang, karena dengan kurangnya disiplin, pekerjaan yang seharusnya sesuai apa yang diharapkan oleh perusahaan maka tidak akan tercapai. Permasalahan Disiplin Kerja yang menonjol dalam perusahaan ini diantaranya adalah tentang displin waktu yaitu berupa karyawan yang sering terlambat masuk kerja, karyawan yang tidak masuk tanpa izin atau alpha. Tidak hanya masalah displin waktu saja, juga kurangnya tanggung jawab dalam melakukan pekerjaan. Kurangnya disiplin dalam bekerja menjadikan pekerjaan yang dikerjakan tidak sesuai apa yang diharapkan oleh perusahaan. Kurangnya Displin Kerja pada karyawan bagian delivery akan mengakibatkan aktifitas menurun. Seperti ketika karyawan bagian delivery terlambat masuk kerja, yang dapat mengakibatkan pada keterlambatan dalam pendisitribusian barang kepada konsumen yang tidak sesuai dengan jadwal yang ada. Hal lain yang bisa menajadikan permasalahan adalah ketika karyawan kurang mematuhi peraturan yang ada dalam perusahaan seperti kurang ketelitian pekerja dalam mengecek barang saat mendistribusikan barang ke konsumen, kurang teliti dalam pendsitribusian barang ke konsumen menyebabkan barang menjadi tertukar. Kesalahan ini sering terjadi dikarenakan kurang disiplinnya karyawan dalam melakukan pekerjaan.

\subsection{Perumusan Masalah}

Berdasarkan uraian latar belakang masalah tersebut di atas maka pokok masalah dalam penelitian ini dapat diuraikan sebagai berikut?

1. Apakah Kompensasi berpengaruh terhadap Kinerja Karyawan di PT. Mulia Sukses Jaya?

2. Apakah Displin Kerja berpengaruh terhadap Kinerja Karyawan di PT.Mulia Sukses Jaya?

3. Apakah Kompensasi dan Disiplin Kerja berpengaruh terhadap Kinerja Karyawan di PT.Mulia Sukses Jaya?

\subsection{Tujuan Penelitian}

Tujuan dari penelitian ini adalah:

1. Untuk mengetahui pengaruh Kompensasi terhadap Kinerja Karyawan di PT. Mulia Sukses Jaya.

2. Untuk mengetahui pengaruh Disiplin kerja terhadap Kinerja Karyawan di PT. Mulia Sukses Jaya. 
3. Untuk mengetahui pengaruh Kompensasi dan Displin Kerja terhadap Kinerja Karyawan di PT. Mulia Sukses Jaya.

\subsection{Manfaat Penelitian}

Penelitian ini diharapkan dapat dijadikan sebagai bahan masukan dan pertimbangan bagi perusahaan dalam menentukan langkah yang diambil dalam bidang personalia yang berkaitan dengan kompensasi dan displin kerja dan bisa dijadikan refrensi serta pedoman dalam penelitian lebih lanjut tentang pengaruh kompesasi dan dsiplin kerja terhadap kinerja karyawan dan menjadikan info dan pengetahuan bagi para pembaca.

\section{Tinjauan Pustaka dan Hipotesis}

\subsection{Manajemen Sumber Daya Manusia}

Manajemen sumber daya manusia diciptikan untuk membentuk kultur perusahaan yang layak, dan memasukan progam - progam yang menggambarkan dan mendukung nilai - nilai pokok dari perusahaan tersebut dan memastikan keberhasilanya. Hasibuan (2014:10) mengemukakan bahwa "Manajemen sumber daya manusia adalah ilmu dan seni mengatur hubungan dan peranan tenaga kerja agar efektif dan efesien untuk membantu terwujudnya tujuan perusahaan, karyawan dan masyarakat", sedangkan Hamali (2018:5) mengemukakan : "Manajemen sumber daya manusia suatu perencanaan, pengorganisasian, pengkoordinasian, pelaksanaan, dan pengawasan terhadap pengadaan, pengembangan, pemberian balas jasa, pengintergrasian, prmrliharaan dan pemisahan tenaga kerja dalam rangka tujuan organsasi.”

\subsection{Kompensasi}

Kompensasi adalah segala sesuatu yang diterima oleh pegawai atau pekerja karena sudah menyelesaikan pekerjaan yang diberikan dengan baik. Badriyah (2015:154) mengemukakan bahwa "Kompensasi kegiatan pemberian balas jasa kepada pegawai, kegiatan disini meliputi penentuan sistem kompensasi yang mampu mendorong prestasi pegawai dan menentukan besarnya kompensasi yang diterima oleh tiap-tiap pegawai". Mulyadi (2015:11) menyatakan bahwa "Setiap bentuk yang diberikan kepada seluruh karyawan sebagai balas jasa atas kontribusi yang diberikan perusahaan atau organisasi". Handoko (2014:155) menyatakan bahwa "kompensasi adalah segala sesuatu yang diterima para para karyawan sebagai balas jasa untuk kerja mereka”.

\subsection{Disiplin Kerja}

Disiplin Kerja merupakan sikap, tingkah laku, dan perbuatan karyawan yang sesuai peraturan dari perusahaan, baik tertulis maupun tidak tertulis. Pengertian displin kerja yamg dikemukakan oleh beberapa ahli : Sutrsino (2014:86) mengemukakan "Disiplin kerja merupakan sikap kesediaan dan kerelaan seseorang untuk mematuhi dan menaati norma - norma peraturan yang berlaku disekitarnya". Hasibuan (2013:83) menyatakan Displin Kerja adalah: "merupakan kesadaran dan kesedian seseorang dalam menaati semua peraturan-peraturan perusahaan dan norma-norma yang berlaku”. Dan Mangkunegara (2013:91) mengemukakan Displin Kerja adalah 
"Merupakan suatu alat yag digunakan pemimpin untuk mengubah suatu perilaku serta sebagai suatu upaya untuk meningkatkan kesadaran dan kesediaan seseorang untuk menaati semua peraturan organisasi serta norma-norma sosial yang ada".

\subsection{Kinerja Karyawan}

Kinerja merupakan hasil pekerjaan yang mempunyai hubungan kuat dengan tujuan organisasi, kepuasan konsumen, dan memberikan kontribusi pada ekonomi. Kinerja merupakan tentang melakukan pekerjaan dan hasil yang dicapai dari pekerjaan tersebut. Mangkunegara (2017:67) mengemukakan kinerja adalah: "Hasil kerja secara kualitas dan kuantitas yang dicapai oleh seorang pegawai dalam melaksanakan tugansnya sesuai tanggung jawab yang diberikan kepadanya". Bintoro dkk (2017:105) mengemukakan "Kinerja karyawan adalah kesedian seseorang atau kelompok orang unutk melakukan kegiatan atau menyempurnakannya dengan sesuai tanggung jawabnya dan dengan hasil yang seperti diharapkanya. Sinambela(2016:481) mengemukakan "Kinerja adalah suatu fungsi dari motivasi dan kemampuan. Untuk menyelesaikan tugas dan pekerjaan, seseorang harus memiliki derajat kesedian dan tingkat kemampuan tertentu. Kesedian dan keterampilan sesorang tidaklah cukup efektif untuk mengerjakan sesuatu tanpa pemahaman yang jelas tentang apa yang dikerjakan dan bagaimana mengerjakanya"

Hasil Penelitian terdahulu yang dilakukan oleh Selvi Viana, 2018 dengan judul penelitian Pengaruh Kompensasi dan Disiplin Kerja terhadap Kinerja Karyawan studi kasus PT.Gema Lintas Semesta dengan hasil penelitian diperoleh taraf signifikan kompnesasi sebesar 0,705 dan Thitung sebesar 6,762 menunjukan bahwa Thitung 6,762 > Ttable 1,689 dan tingkat signifikansi t lebih kecil dari 0,05 (Signifikan $\mathrm{T}=$ $0,000,0,05)$. Maka Ha diterima dan Ho ditolak. Dan dapat disimpulakan secara parsial variable Kompensasi mempunyai pengaruh terhadap kinerja karyawan. Sedangkan untuk variable disiplin kerja nilai koefisien sebesar 0,215 dengan Thitung sebesar 1,756 > 7,687 dan tingkat signifikan $\mathrm{T}$ lebih besar dari 0,05. (signifikan dapat disimpulkan secara parsial variable disiplin kerja tidak mempunyai pengaruh yang positif dan signifikan terhadap variable kinerja karyawan. Adapun nilai t table berasal dari perhitungan dan rumus $n-k$, dimana $n=$ banyaknya obeservsi sedangkan $k=$ banyaknya variable (bebas dan terikat) $\mathrm{df}=\mathrm{n}-\mathrm{k}, 40-3=7$ dan bila dilihat table $\mathrm{T}$ dengan memakai tingkat kesalahan penelitian 5\% $(0,05)$ maka akan mendapat nilai 1,687. Sedangkan analisis bahwa Fhitung sebesar 25,006 lebih dari F table yaitu 3,25 dengan nilai signifikan 0,000 yang berarti dibawah 0,05. Maka Ho ditolak dan Ha diterima.

\section{Metodologi Penelitian}

Sumber data yang diperlukan dalam penelitian ini adalah data yang diperoleh dari responden melalui kuesioner, kelompok fokus, dan panel atau juga data hasil wawancara peneliti dengan narasumber. Teknik pengumpulan data merupakan cara yang dilakukan peneliti untuk mengungkap atau menjaring informasi kuantitatif dari responden sesuai lingkup penelitian. Dalam penelitian ini teknik pengumpulan data yang digunakan adalah dengan menggunkan metode Kusioner atau Angket, merupakan teknik pengumpulan data yang dilakukan dengan cara memberi seperangkat pertanyaan atau pernyataan tertulis kepada para reponden untuk dijawab.

Uji validitas digunakan untuk mengukur sah atau valid tidaknya suatu kuesioner". Suatu kuesioner dikatakan sah atau valid jika pertanyaan pada kuesioner tersebut mampu 
mengungkapkan sesuatu yang diukur oleh kuesinoer itu. Hasil $r$ hitung dibandingkan dengan $\mathrm{r}$ tabel, dimana $\mathrm{df}=\mathrm{n}-2$, dengan sig 5\%, jika $\mathrm{r}$ tabel $<\mathrm{r}$ hitung maka valid. Uji ini menggunakan teknik kolerasi product moment. Rumus uji validitas sebagai berikut:

$$
\mathrm{r}=\frac{n \sum X Y-\left(\sum X\right)\left(\sum Y\right)}{\left.\sqrt{\left[n \sum X^{2}\right.}-(X)^{2}\right]\left[n \sum Y^{2}-\left(\sum Y\right)^{2}\right.}
$$

Dimana :

$\mathrm{r} \quad=$ koofesien kolerasi

$\sum X=$ jumlah skor atau nilai untuk setiap faktor

$\mathrm{N}=$ jumlah individu atau responden dalam sampel

$\sum \mathrm{Y}=$ jumlah skor atau nilai seluruh item

\section{Uji T}

Uji t adalah pengujian koefisien regresi parsial individual yang digunakan unutk mengetahui apakah variable indpenden $(\mathrm{X})$ secara individual mempengaruhi dependen (Y). Untuk menguji hipotesis dapat menggunakan rumus sebagai berikut:

$$
\mathrm{t}=\frac{r \sqrt{n-2}}{\sqrt{1-r^{2}}}
$$

Dengan hipotesis :

1. $\quad \mathrm{Ho}=$ Tidak terdapat hubungan signifikan variabel $\mathrm{X}$ dengan $\mathrm{Y}$

2. $\quad \mathrm{Ha}=$ Terdapat hubungan signifikan varabel $\mathrm{X}$ dengan $\mathrm{Y}$

Dengan ketentuan :

1. Jika $t$ hitung $>t$ tabel maka Ha diterima dan Ho ditolak

2. Jika $t$ hitung $<\mathrm{t}$ tabel maka Ha ditolak dan Ho diterima

\section{Uji F}

Uji f adalah pengujian signifikan persamaan yang digunakan untuk mengetahui seberapa besar pengaruh $\left(\mathrm{X}_{1}, \mathrm{X}_{2}\right)$ secara bersama-sama terhadap variable tidak bebas $(\mathrm{Y})$ yaitu Kinerja Karyawan. Sugiyono (2014:257) mengemukan rumusnya sebagai berikut:

$$
\mathrm{F}=\frac{R^{2} / K}{\left(1-R^{2}\right) \cdot(N-K-1)}
$$

Keterangan :

$\mathrm{F}=$ Fhitung yang selanjutnya dikonsultasikan dengan $\mathrm{F}_{\text {tabel }}$

$\mathrm{R}^{2}=$ Koefisien Determinasi

$\mathrm{n}=$ Jumlah sampel

$\mathrm{K}=$ Jumlah variabel bebas 


\section{Hasil Penelitian Dan Pembahasan}

\subsection{Gambaran Umum Objek Penelitian}

PT.Mulia Sukses jaya adalah perusahaan yang berbasis di Indonesia, didirikan pada 13 April 1999 yang beralamatkan kantor di Grand Slipi Tower lantai 10 unit m,n,o Jl. Jendral.S.Parman Kav 22 -24 Jakarta Barat - DKI Jakarta dan beralamatkan warehouse di Jl.Raya Narogong Km. 26,5 Desa Klapanunggal - Kecamatan Klapanunggal - Kabupaten Bogor. PT. Mulia Sukses Jaya adalah perusahaan yang bergerak di bidang distributor elektronik rumah tangga seperti kompor, penyedot asap, microwave, oven, dispenser, refrigator dan lain sebagainya. Brand atau merk yang dipasarkan oleh PT. Mulia Sukses jaya adalah Ariston, Delizia, Royal, LaGermania, Bertazoni, Scholtes, Supor dan Tefal. Dalam hal pemasaranya PT. Mulia Sukses jaya membuka showroom dengan nama KitchenArt di berbagai mall besar di Jakarta seperti Mall Taman Anggrek, Mall Central Park, Jakarta Design Center (JDC), Mall Artha Gading, Emporimu Pluit Mall, Baywalk Mall, Gandaria City Mall, dan Rosville Gallery di Serpong. Selain membuka showroom, pemasaran produk juga bekerja dengan online shop dan juga toko atau modern outlet yang ada di kota - kota besar di Indonesia Untuk memperluas pemasaran produknya PT.Mulia Sukses Jaya Juga membuka benyak cabang di kota - kota besar di Indonesia seperti di Bandung, Jogja, Semarang, Surabaya, Bali, Makassar, Manado, Balikpapan, Pekanbaru dan Medan. PT. Mulia Sukses jaya berkomitmen kuat untuk melayani pasar dan masyarakat, berusaha untuk terus mempertahankan dan meningkatkan standar tinggi yang telah kami janjikan kepada konsumen. Mendedikasikan untuk menyediakan produk dengan kemajuan teknologi terbaru kepada pelanggan. Dengan tim manajemen yang kuat dan profesional yang didukung oleh para pemimpin yang berpengalaman, PT. Mulia Sukses Jaya telah mendapatkan kepercayaan dan dukungan dari prinsip-prinsip merek kami. Saat ini, Perusahaan ini telah berkembang menjadi rumah bagi merek-merek terkemuka dunia.

\subsection{Hasil Penelitian}

Pengujian ini dilakukan untuk mengetahui apakah nilai residual terdistribusi normal atau tidak. Dalam pengujian uji normalitas ini dilakukan dengan uji probality plot dan uji kolmogrov dengan nilai signifikan $>0,05$ maka nilai residual berdistribusi normal sedangkan jika nilai signifikan $<$ dari 0,05 maka nilai residual tidak bersitribusi normal. Hasil uji normalitas dengan kolmogrov smirnov dapat dilihat sebagai berikut 
Tabel 4.1

Hasil Uji Normalitas

One-Sample Kolmogorov-Smirnov Test

\begin{tabular}{|l|l|r|}
\hline N & & 30 \\
\hline Normal Parameters & Mean & 0,0000000 \\
\cline { 2 - 3 } & Std. Deviation & 1,89748018 \\
\hline Most Extreme Differences & Absolute & 0,136 \\
\cline { 2 - 3 } & Positive & 0,136 \\
\cline { 2 - 3 } & Negative & $-0,076$ \\
\hline Test Statistic & & 0,136 \\
\hline Asymp. Sig. (2-tailed) & &, $166^{\mathrm{c}}$ \\
\hline
\end{tabular}

a. Test distribution is Normal.

b. Calculated from data.

Sumber: Hasil pengolahan data SPSS 26

Berdasarkan tabel 4.1. hasil uji normalitas yang telah dilakukan dengan Kolmogrov Smirnov dapat diketahui bahwa data terdistribusi normal. Hal ini dapat dilihat dari nilai Asymp. Sig (2tailed) sebesar 0,166 lebih besar dari 0,05 dengan ini dikatakan bahwa data terdistribusi normal. Dan selanjutnya dilakukan uji normalitas dengan dengan model P-P Plot of Regression Standarzed Residual. Untuk mengetahui apakah data terdistribusi normal dapat dilihat dari gambar 4.2 bahwa terlihat titik menyebar disekitar garis diagonal dan mengikut arah garis diagonal. Maka dapat disimpulkan data terdistribusi secara normal.

\section{Gambar 4.1}

\section{Uji Normalitas P-P Plot}

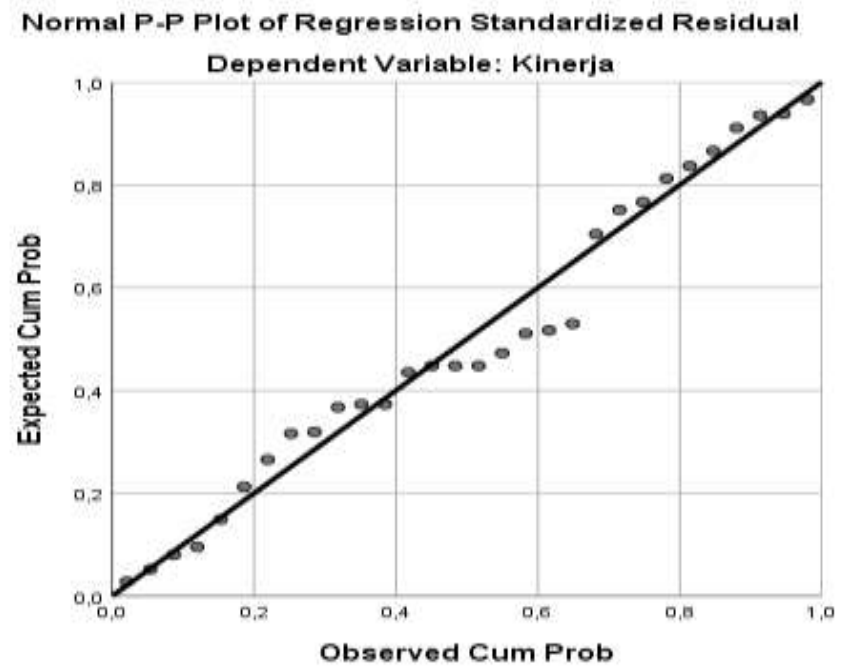

Sumber : Hasil pengelolahan data SPSS 26. 
Analisa Regresi Sederhana digunakan untuk mengetahui pengaruh variabel bebas $\mathrm{X}_{1}$ (Kompensasi) atau $\mathrm{X}_{2}$ (Disiplin Kerja) terhadap variabel terikat Y (Kinerja).

Tabel 4.2

Hasil Analisis Regresi Sederhana antara X1 dan Y

\begin{tabular}{|c|c|c|c|c|c|c|}
\hline & & \multicolumn{2}{|c|}{$\begin{array}{l}\text { Unstandardized } \\
\text { Coefficients }\end{array}$} & $\begin{array}{l}\text { Standardized } \\
\text { Coefficients }\end{array}$ & \multirow[b]{2}{*}{$\mathrm{T}$} & \multirow[b]{2}{*}{ Sig. } \\
\hline \multicolumn{2}{|c|}{ Model } & B & Std. Error & Beta & & \\
\hline \multirow[t]{2}{*}{1} & (Constant) & 17,333 & 6,553 & & 2,645 & 0,013 \\
\hline & Kompensasi & 0,416 & 0,190 & 0,383 & 2,192 & 0,037 \\
\hline
\end{tabular}

a. Dependent Variable: Kinerja

Sumber: Hasil pengolahan data SPSS 26

Berdasarkan tabel 4.2 di atas hasil analisis regresi sederhana didapatkan persamaan regresi:

$\mathrm{Y}=17,333+0,416 \mathrm{X} 1$

Dari persamaan diatas dapat dijelaskan :

- Nilai a $=17,333$, artinya jika tidak ada perubahan dari variable Kompensasi X1 maka Kinerja Karyawan Y adalah 17,333

- Nilai $b=0,416$ artinya setiap penambahan satu skor pada variable Kompensasi maka Kinerja Karyawan akan mengalami penambahan skor sebesar 0,416 dan terjadi hubungan positif antara Kompensasi dengan Kinerja Karyawan

Tabel 4.3

Hasil Regresi Sederhana antara X2 dan Y

\begin{tabular}{|c|c|c|c|c|c|c|}
\hline \multirow{2}{*}{\multicolumn{2}{|c|}{ Model }} & \multicolumn{2}{|c|}{$\begin{array}{l}\text { Unstandardized } \\
\text { Coefficients }\end{array}$} & \multirow{2}{*}{$\begin{array}{c}\text { Standardized } \\
\text { Coefficients } \\
\text { Beta } \\
\end{array}$} & \multirow[b]{2}{*}{$\mathrm{t}$} & \multirow[b]{2}{*}{ Sig. } \\
\hline & & B & Std, Error & & & \\
\hline 1 & (Constant) & 12,566 & 3,781 & & 3,323 & 0,002 \\
\hline & Disiplin Kerja & 0,630 & 0,124 & 0,692 & 5,074 & 0,000 \\
\hline
\end{tabular}

a. Dependent Variable: Kinerja

Sumber: Hasil pengolahan data SPSS 26

Berdasarkan tabel 4.3 di atas hasil analisis regresi sederhana didapatkan persamaan regresi:

$\mathrm{Y}=12,566+0,630 \mathrm{X} 2$

Dari persamaan diatas dapat dijelaskan :

- Nilai a $=12,566$, artinya jika tidak ada perubahan dari variable Kompensasi X1 maka Kinerja Karyawan Y adalah 12,566

- Nilai $b=0,630$ artinya setiap penambahan satu skor pada variable Disiplin Kerja X2 maka Kinerja Karyawan Y akan mengalami penambahan skor sebesar 0,630 dan terjadi hubungan positif antara Disiplin Kerja dengan Kinerja Karyawan. 
Analisis berganda untuk mengetahui pengaruh hubungan variable bebas Kompensasi $\mathrm{X}_{1}$, Displin Kerja $\mathrm{X}_{2}$ terhadap Kinerja Karyawan $\mathrm{Y}$ secara linear.

Tabel 4.4

Hasil Analisis Regresi Berganda

\begin{tabular}{|c|c|c|c|c|c|c|}
\hline & & \multicolumn{2}{|c|}{$\begin{array}{l}\text { Unstandardized } \\
\text { Coefficients }\end{array}$} & \multirow{2}{*}{$\begin{array}{c}\begin{array}{c}\text { Standardized } \\
\text { Coefficients }\end{array} \\
\text { Beta }\end{array}$} & \multirow[b]{2}{*}{$\mathrm{T}$} & \multirow[b]{2}{*}{ Sig. } \\
\hline \multicolumn{2}{|c|}{ Model } & B & Std. Error & & & \\
\hline \multirow[t]{3}{*}{1} & (Constant) & 10,437 & 5,438 & & 1,919 & 0,066 \\
\hline & Kompensasi & 0,093 & 0,169 & 0,086 & 0,552 & 0,586 \\
\hline & Disiplin Kerja & 0,595 & 0,141 & 0,653 & 4,211 & 0,000 \\
\hline
\end{tabular}

a. Dependent Variable: Kinerja

Sumber: Hasil pengolahan data SPSS 26

Bersasarkan tabel 4.4 hasil analsis regresi berganda antara variable Kompensasi X1 dan Disiplin Kerja X2 dapat disusun persamaan regresi sebagai berikut:

$\mathrm{Y}=10,437+0,093 \mathrm{X} 1+0,595 \mathrm{X} 2$

Persamaan regresi diatas dapat dijelaskan sebagai berikut:

- Nilai a $=10,437$ artinya jika tidak ada perubahan atau kenaikan variable Kompensasi X1 dan Disiplin Kerja X2 maka Kinerja Karyawan adalah 10,437

- Nilai b1 = 0,093 artinya jika setiap ada penambahan satu skor nilai dari Variable Kompensasi maka Kinerja Karyawan akan ada penambahan skor sebesar 0,093 pada saat Disiplin Kerja X1 sebesar $=0$

- Nilai b2 =0,595 artinya jika setiap ada penambahan satu skor dari variable Disiplin Kerja maka Kinerja Karyawan akan ada penambahan skor sebesar 0,595 pada saat Kompensasi $\mathrm{X} 1=0$

Analisis Koeralsi Sederhana digunakan unuk mengetahui keeratan hubungan antara dua varible dan untuk mengetahui arah hubungan yag terjadi.

Tabel 4.5

Hasil Uji Korelasi Sederhana antara X1 dengan Y Model Summary

\begin{tabular}{|l|r|r|r|r|}
\hline Model & $\mathrm{R}$ & R Square & $\begin{array}{l}\text { Adjusted } \\
\text { R Square }\end{array}$ & $\begin{array}{c}\text { Std. Error of the } \\
\text { Estimate }\end{array}$ \\
\hline 1 &, $383^{\mathrm{a}}$ & 0,147 & 0,116 & 2,48548 \\
\hline
\end{tabular}

a. Predictors: (Constant), Kompensasi

Sumber : Hasil pengolahan data SPSS 26

Berdasarkan tabel 4.5 dapat diketahui bahwa nilai korelasi R antara Kompensasi X1 dengan Kinerja Karyawan Y sebesar 0,383 yang artinya terdapat pengaruh yang rendah dan positif. Sedangkan nilai R Square sebesar 0,147 atau 14,7\% yang artinya 
variable Kompensasi memberi konstribusi terhadap Kinerja Karyawan Y sebesar $14,7 \%$ sedangkan sisanya $85,3 \%$ lainya dipengaruhi oleh faktor yang tidak di bahas dalam penelitian ini.

Tabel 4.6

Hasil Uji Korelasi Sederhana antara X2 dengan Y

Model Summary

\begin{tabular}{|l|r|r|r|r|}
\hline Model & R & R Square & $\begin{array}{c}\text { Adjusted R } \\
\text { Square }\end{array}$ & $\begin{array}{c}\text { Std. Error of the } \\
\text { Estimate }\end{array}$ \\
\hline 1 &, $692^{\mathrm{a}}$ & 0,479 & 0,460 & 1,942 \\
\hline
\end{tabular}

a. Predictors: (Constant), Disiplin Kerja

Sumber : Hasil pengolahan data SPSS 26

Berdasarkan tabel 4.6 dapat diketahui bahwa nilai korelasi R antara Disiplin Kerja X2 dengan Kinerja Karyawan Y sebesar 0,692 yang artinya terdapat pengaruh yang kuat dan positif. Sedangkan nilai R Square sebesar 0,479 atau 47,9\% yang artinya variable Disiplin Kerja X2 memberi konstribusi terhadap Kinerja Karyawan Y sebesar 47,9\% sedangkan sisanya $52,1 \%$ lainya dipengaruhi oleh faktor yang tidak di bahas dalam penelitian ini.

Analisa korelasi berganda digunakan untuk megetahui besarnya atau kekuatan hubungan antara variable bebas Kompensasi X1 dan Disiplin Kerja X2 terhadap varible terikat Kinerja Karyawan Y secara bersamaan. Hasil perhitungan korelasi berganda sebagai berikut:

Tabel 4.7

Hasil Uji Korelasi Berganda Model Summary

\begin{tabular}{|l|r|r|r|r|}
\hline Model & R & R Square & \multicolumn{1}{c|}{$\begin{array}{c}\text { Adjusted R } \\
\text { Square }\end{array}$} & $\begin{array}{c}\text { Std. Error of the } \\
\text { Estimate }\end{array}$ \\
\hline 1 &, $696^{\mathrm{a}}$ & 0,485 & 0,447 & 1,96650 \\
\hline
\end{tabular}

a. Predictors: (Constant), Disiplin Kerja, Kompensasi

Sumber: Hasi pengolahan data SPSS 26

Berdasarkan tabel 4.7 diatas dari perhitungan yang dapat diketahui nilai korelasi $\mathrm{R}$ Kompensasi X1 dan Disiplin Kerja X2 terhadap Kinerja Karyawan sebesar 0,696 yang artinya kedua variable independen Kompensasi X1 dan Disiplin Kerja X2 mempunyai hubungan yang kuat dan positif terhadap variable dependen Kinerja Karyawan Y.

Uji $\mathrm{f}$ adalah pengujian signifikan persamaan yang digunakan untuk mengetahui seberapa besar pengaruh Kompensasi $X_{1}$ dan Disiplin Kerja $\mathrm{X}_{2}$ secara bersama-sama terhadap variable tidak bebas $\mathrm{Y}$ yaitu Kinerja Karyawan.

Ha diterima dan Ho ditolak jika $: F_{\text {hitung }}>F_{\text {tabel }}$ atau Sig $F<a=0,05$

Ha ditolak dan Ho diterima jika : $F_{\text {hitung }}<F_{\text {tabel }}$ atau Sig $F>a=0,05$

Jika Ha diterima maka ada pengaruh postif dan signifikan secara simultan atau bersama - sama variable indepedend terhadap variable dependen, dan sebaliknya jika Ha ditolak maka tidak ada pengaruh positif dan signifikan secara simultan atau 
bersama - sama antara variable indeoenden terhadap variable dependen. Berdasarkan uji f yang dilakukan maka hasilnya sebagai berikut:

\begin{tabular}{|c|c|c|c|c|c|c|}
\hline \multicolumn{7}{|c|}{$\begin{array}{c}\text { Tabel } 4.8 \\
\text { Hasil Uji F } \\
\text { ANOVA }^{\mathrm{a}}\end{array}$} \\
\hline \multicolumn{2}{|r|}{ Model } & $\begin{array}{l}\text { Sum of } \\
\text { Squares }\end{array}$ & $\mathrm{df}$ & Mean Square & $\mathrm{F}$ & Sig. \\
\hline \multirow[t]{3}{*}{1} & Regression & 98.254 & 2 & 49.127 & 12.704 &, $000^{\mathrm{b}}$ \\
\hline & Residual & 104.412 & 27 & 3.867 & & \\
\hline & Total & 202.667 & 29 & & & \\
\hline
\end{tabular}

a. Dependent Variable: Kinerja

b. Predictors: (Constant), Disiplin Kerja, Kompensasi

Sumber: Hasil Pengolahan data SPSS

Dari hasil table 4.8 perhitungan uji f dapat diketahui nilai fhitung adalah 12,704 dan taraf signifikansi sebesar 0,000 . jadi nilai $\mathrm{f}_{\text {hitung }} 12,704>3,35$ nilai $\mathrm{f}_{\text {tabel }}$ dan nilai taraf signifikasi $0.000<0,05$. Dengan ini maka Ha diterima dan Ho ditolak yang artinya Kompensasi dan Disiplin Kerja secara bersama - sama berpengaruh positif dan signifikan terhadap Kinerja Karyawan pada PT.mulia Sukses Jaya.

Adapun nilai ftabel didapatkan dari perhitungan dengan rumus Df $2=\mathrm{n}-\mathrm{k}$ yaitu dimana $\mathrm{n}$ banyaknya sample dan $\mathrm{k}$ banyaknya variable independen dan dependen. Dengan ini Df2 $30-2-1=27$ dan bisa dilihat pada ftabel dengan memakai tingkat kesalahan penelitian $0,05(5 \%)$ maka akan mendapat nilai 3,35.

\subsection{Pembahasan}

\subsubsection{Pengaruh Kompensasi Terhadap Kinerja Karyawan}

Berdasarkan analisa data dan uji hipotesa t menunjukan bahwa variable kompensasi secara pasial berpengaruh signifikan terhadap kinerja karyawan dengan tingkat signifikansi adalah 0,037<0,05 dan thitung 2,192 > 2,052 ttable. Secara statistik nilai koefisien beta 0,383 bernilai positif yang menunjukan adanya pengaruh. Artinya bahwa Ho ditolak dan Ha diterima. Dengan demikian hipotesis yang menyatakan Kompensasi berpengaruh positif signifikan terhadap Kinerja Karyawan (Ha) diterima.

Hasil ini dari peneltian ini sesuai dengan hasil peneltian yang dilakukan oleh Siti Maria, 2017 dengan judul dengan judul Pengaruh Kompensasi dan Disiplin Kerja terhadap Kinerja Guru pada SMK Insan Bhakti Mulia Pondok Gede Bekasi. Dengan taraf signifikan Kompensasi 0,014 dan thitung sebesar 2,556 menunjukan bahwa tingkat signifikan $0,014<0,05$ dan thitung 2,556 2,019 ttabel yang berarti Kompensasi berpengaruh signifikan terhadap Kinerja Guru. Jadi faktor kompensasi sangat berpengaruh untuk membantu meningkatkan Kinerja Karyawan dikarenakan Kompensasi merupakan hasil yang diterima oleh karyawan yang diberikan oleh perusahaan atas pekerjaan mereka. Pemberian kompensasi yang belum maksimal berdampak pada Kinerja para karyawan. 


\subsubsection{Pengaruh Disiplin Kerja Terhadap Kinerja Karyawan}

Berdasarkan analisa data dan uji hipotesa t menunjukan bahwa variable Disiplin Kerja secara parsial berpengaruh signifikan terhadap Kinerja Karyawan dengan tingkat signifikan $0,000<0,05$ dan nilai thitung 5,074>2,052 ttable. Secara statistik nilai koefisien beta 0,692 bernilai positif yang menunjukan adanya pengaruh. Artinya bahwa Ho ditolak dan Ha diterima. Dengan demikian hipotesis yang menyatakan Disiplin Kerja berpengaruh positif signifikan terhadap kinerja karyawan (Ha) diterima. Hasil dari penelitian ini sesuai dengan penelitian yang dilakukan oleh Popy Rachman, 2018 dengan judul Pengaruh Kompensasi dan Disiplin Kerja terhadap Kinerja Karyawan. Dengan taraf signifikan 0,006 $<0,05$ dan nilai thitung 2,986 $>1,687$ ttabel yang berarti bahwa Disiplin Kerja berpengaruh signifikan terhadap Kinerja Karyawan. Jadi faktor Disiplin Kerja berpengaruh untuk meningkatkan Kinerja Karyawan dikarenakena dengan penerapan Disiplin Kerja yang tepat dan sesuai akan mempengaruhi kualitas Kinerja Karyawa PT. Mulia Sukses Jaya.

\subsection{Pengaruh Kompensasi dan Kinerja Karyawan Terhadap Kinerja Karyawan}

Berdasarkan analisa data dan hipotesa dalam penelitian ini menunjukan bahwa secara simultan Kompensasi dan Disiplin Kerja berpengaruh positif dan signifikan terhadap Kinerja Karyawan dengan taraf signifikan f sebesar 0.000 dan fhitung 12,704 menunjukan bahwa nilai signifikan $0,000<0,05$ dan nilai fhitung $>3,35$ ftable. Artinya bahwa Ho ditolak dan Ha diterima, dengan demikian bahwa Kompensasi dan Disiplin Kerja bersama - sama berpengaruh positif dan signifikan terhadap Kinerja Karyawan PT. Mulia Sukses Jaya. Hasil penelitian ini sesuai dengan penelitian yang dilakukan oleh Hardyanto dengan judul Pengaruh Kompensasi dan Disiplin Kerja terhadap Kinerja Karyawan dengan hasil uji f signifikan dengan nilai $0,000<0,05$ dan nilai fhitung 43,094 > 3,347 ftabel maka Ho ditolak dan Ha diterima yang artinya bahwa Kompensasi dan Disiplin Kerja bersama - sama berpengaruh positif dan signifikan terhadap Kinerja Karyawan.

\section{Simpulan dan Saran}

\subsection{Simpulan}

Berdasarkan hasil penelitian yang telah dilakukan mengenai Pengaruh Kompensai dan Disiplin Kerja terhadap Kinerja Karyawan PT. Mulia Sukses Jaya maka dapat disimpulkan sebagai berikut:

1. Berdasarkan hasil regresi sederhana antara X1 dengan $Y$, artinya bahwa terjadi hubungan positif antara Kompensasi X1 dengan Kinerja Karyawan Y dengan nilai koefisien 0,416 dan nilai signifikansi sebesar $0.037<0,05$. Maka dapat disimpulkan pemberian Kompensasi yang semakin besar juga akan diikuti dengan peningkatan Kinerja Karyawan PT. Mulia Sukses Jaya.

2. Berdasarkan hasil regresi sederhana antara $\mathrm{X} 2$ dengan $\mathrm{Y}$, artinya bahwa terjadi hubungan positif antara Disiplin Kerja X2 dengan Kinerja Karyawan Y dengan nilai koefisien 0,630 dan nilai signifikansi sebesar $0.000<0,05$. Dapat disimpulkan bahwa semakin tinggi penerapan Disiplin Kerja pada karyawan PT. Mulia Sukses Jaya maka semakin tinggi Kinerja Karywan.

3. Berdasarkan hasil uji korelasi sederhana dapat dilihat seberapa kuat pengaruh variable Kompensasi X1 berpengaruh terhadap variable Kinerja Karyawan Y. Dengan nilai R 
0,383 dan nilai $\mathrm{R}$ Square sebesar 0,147 dapat diartikan bahwa Kompensasi berpengaruh rendah terhadap Kinerja Karyawan dan Kompensasi meberikan kontribusi sebesar 14,7\% terhadap Kinerja Karyawan. Sedangkan Disiplin Kerja X2 mendapatkan nilai $\mathrm{R}$ sebesar 0,692 dan nilai $\mathrm{R}$ Square sebesar 0,479 yang artinya bahwa Disiplin Kerja X2 bepengaruh kuat terhadap Kinerja Karyawan Y dan Disiplin Kerja memberi kontribusi terhadap Kinerja Karywan sebesar 47,9\%.

4. Berdasarkan hasil uji korelasi berganda diketahui bahwa variable independen Kompensai dan Disiplin Kerja mempunyai nilai $\mathrm{R}$ sebesar 0,696 terhadap variable dependen Kinerja Karyawan. Artinya bahwa variable independen Kompensasi dan Disiplin Kerja mempunyai pengaruh yang kuat dan positif terhadap variable dependen Kinerja Karyawan.

5. Berdasarkan hasil uji t antara Kompensasi X1 dengan Kinerja Karyawan Y dapat disimpulkan bahwa variable Kompensasi X1 memperoleh nilai signifikan sebesar $0,037<0,05$ sedangkan nilai thitung 2,192 > ttable 2,052, yang berarti Kompensasi X1 Signifikan maka Ha diterima dan Ho ditolak. Artinya bahwa Kompensasi berpengaruh signifikan terhadap Kinerja Karywan.

6. Sedangka hasil uji t antara Disiplin Kerja X2 dengan Kinerja Karyawan $\mathrm{Y}$ dapat disimpulkan bahwa variable Disiplin Kera X2 memperoleh nilai signifikan sebesar $0,000<0,05$ sedangkan nilai thitung 5,074 > 2,052 ttabel yang berartti Disiplin Kerja signifikan X2 maka Ha diterima dan Ho ditolak. Artinya bahwa Disiplin Kerja Berpengaruh signifikan terhadap Kinerja Karyawan PT. Mulia Sukses Jaya.

7. Berdasarkan dari uji f antar Kompensasi X1 dan Disiplin Kerja X2 dengan Kinerja Karyawan Y dapat disimpulkan bahwa nilai signifikansi sebesar $0,000<0,05$ dan nilai fhitung sebesar 12,704 > 3,35 nilai ftabel. Maka Ha diterima dan Ho ditolak. Artinya bahwa Kompensasi dan Disiplin Kerja bersama - sama berpengaruh positif dan signifikan terhadap Kinerja Karywan PT. Mulia Sukses Jaya.

8. Berdasarkan uji koefisien determinasi R2 dapat disimpulkan bahwa nilai koefisen determinasi sebesar 0,485 yang artinya bahwa variable independen Kompensasi X1 dan Disiplin Kerja X2 memliki kontribusi sebesar 48,5\% terhadap variable dependen Kinerja Karyawan Y. sedangkan sisnya sebesar 51,5\% lainya di kontribusikan oleh faktor lain yang tidak dimasukan dalam variable penelitian ini.

\subsection{Saran}

Berdasarkan peneltian yang sudah dilakukan dan kuesioner yang disebar terhadap responden penulis menyampaikan saran mengenai masalah Kompensasi $\mathrm{X}_{1}$ dan Disiplin Kerja $\mathrm{X}_{2}$ dengan Kinerja Karyawan Y sebagai berikut:

1. Saran untuk pimpinan atau manajemen perusahaan untuk meninjau perihal pemberian upah lembur atau over time yang diberikan kepada karyawan. Dikarenakan sering tidak selesainya pendsitribusian dikarenakan masalah pemberian upah over time yang dirasa karyawan bagian delivery kurang sesuai dengan harapan karaywan. Serta lebih meningkatkan pemberian gaji untuk karayawan baru agar tidak sering terjadi keluar masuknya karayawan dikarenakan tidak sesuai dengan gaji yang diberikan. Hal ini mengakibatkan terganggunya aktifitas pekerajaan dikarenakan karyawan baru harus menyesuaikan dengan pekerjaan barunya.

2. Saran untuk pimpinan dan manajamen perusahaan, untuk lebih memperhatikan masalah disiplin kerja yaitu mengenai karayawan yang sering telambat dan tidak masuk kerja (alpha) agar lebih diperhatikan atau diberikan teguran. Perusahaan juga lebih sering mensosialisasikan kepada karywan mengenai peraturan - peraturan 
disiplin kerja yang ada dalam perusahaan. Agar karyawan lebih mengerti dan mengetahui dengan jelas peraturan yang ada dalam perusahaan. Dengan mengetahui dan mengerti sepenuhnya akan peraturan disiplin kerja yang ada di dalam perusahaan menjadikan pekerjaan yang diberikan kepada pegawai akan berjalan lancar dan sesuai harapan yang diinginkan perusahaan.

3. Bagi peneliti selanjutnya yang mungkin tertatirk mengkaji masalah yang sama yaitu mengenai kompensasi dan disiplin kerja dengan kinerja karyawan diharapkan untuk lebih mengembangkan penelitian ini dengan populasi atau sample yang lebih banyak dan dengan ruang lingkup yang lebih luas juga. Disarankan juga untuk yang akan melakukan penelitian untuk mengkaji variable lain seperti SOP, pelatihan kerja, motivasi, rekruitmen atau lingkungan kerja.

\section{Referensi}

Alisa,T.2017. Pengaruh Kompensasi dan Disiplin Kerja Terhadap Kinerja Karyawan pada PT. Tunggal Idaman Abadi. Skripsi Fakultas Ekonomi dan Bisnis Universitas Islam As-Syafiiyah.

Badriyah,M.2015.Manajemen Sumber Daya Manusia.Cetakan ke 1 CV.Pustaka Setia,Bandung

Bintoro,M.T.2017.Manajemen Penilaian Kinerja Karyawan” Cetakan Ke 1 2017, Gava Media, Yogyakarta

Hamali,A.P.2018.Pemahaman Manajemen Sumber Daya Manusia strategi mengelola karyawan. Cetakan ke 1 Yogyakarta.CAPS

Handoko, T.H.2014.Manajemen Personalia dan Sumber Daya Manusia. BPFE. Yogyakarta

Hardyanto.2017. Pengaruh Kompensasi dan Disiplin Kerja terhadap Kinerja Karywan PT.Tuffindo Nittokuv Autoneum. Skripsi Fakultas Ekonom dan Bisnis Universitas Islam As-Syafi'iyah

Hasibuan,M.S.P.2013, Manajemen Sumber Daya Manusia, Catatan ke 7, PT. Bumi Aksara, Jakarta.

Mangkunegara,A.P.2013. Manajemen Sumber Daya Manusia edisi 11 . Remaja Rosdakaya, Bandung

Mulyadi.2015.Manajemen Sumber Daya Manusia.IN MEDIA.Bogor

Maria, S.2017. Pengaruh Displin Kerja dan Kompensasi Terhadap Kinerja Guru Pada SMK Insan Bhakti Mulia Pondok Gede Bekasi. Skripsi Fakultas Ekonomi dan Bisnis Universitas Islam As-Syafiiyah.

Rahman. P.2018. Pengaruh Kompensasi dan Disiplin Kerja Terhadap Kinerja Karyawan Kantor Jasa Penilai Publik Latief, Hanief,dan Rekan Cabang Bekasi

Sinambela,L.P.2016.Manajemen Sumber Daya Manusia: memabngun tim kerja yang solid untuk meningkatkan kinerja. PT.Bumi Aksara, Jakarta 
Sugiyono.2017.Metode Penelitian Kuantitatif,Kualitatif,dan R\&D.Alfabeta,Bandung Sujarweni, W. 2015. Metode Penelitian Bisnis dan Ekonomi. Pustaka Baru Press. Yogyakarta.

Sutrisno, E. 2017.Manajemen Sumber Daya Manusia. Kencana, Rawamangun - Jakarta Umam. K.2010. Perilaku Organisasi. Pustaka Setia, Bandung

Viani, S.2018. Pengaruh Kompensasi dan Disiplin Kerja terhadap Kinerja Karyawan PT. Gema Lintas Semesta. 